\title{
Prevalence of Traffic Noise in Jalandhar City
}

\section{Singh LP*}

Department of Industrial and Production Engineering, Dr BR Ambedkar National Institute of Technology, India

*Corresponding author: L P Singh, Asst. professor, Department of Industrial and Production Engineering, Dr BR Ambedkar National Institute of Technology, Jalandhar-144011, India, E-mail: singhl@nitj.ac.in

\section{Abstract}

Traffic noise becoming a significant environmental quality problem in economically developing countries and a cause of society's increasing annoyance. The present study is focused upon measuring the traffic noise pollution in Jalandhar City. The study included four sites of city. A weighted (Leq) ambient noise was assessed by using a quest sound level meter "model SOUNDPRO SP-DL-1-1/3". OSHA norms for hearing conservation were incorporated including an exchange rate of $5 \mathrm{~dB}(\mathrm{~A})^{*}$, criterion level at $90^{*} \mathrm{~dB}(\mathrm{~A})$, criterion time of eight hours*, threshold level equal to $80 \mathrm{~dB}(\mathrm{~A})$, upper limit equal to $140 \mathrm{~dB}(\mathrm{~A})$ and with $\mathrm{F} / \mathrm{S}$ response rate. The results of the study revealed that interstate bus terminal Jalandhar and Jyoti chowk were found at the highest level of noise pollution due to traffic However Rama mandi and Maqsudan chowk were found moderately polluted area. The study recommended that there is a need of implementing the noise pollution criteria in the city. The appropriate noise control measures should be implemented.

Keywords: Traffic noise; Noise pollution; Punjab; Jalandhar City

Abbreviations: SPL: Sound Pressure Level; SIL = Sound Intensity Level; IHD: Ischemic Heart Disease; WHO: World Health Organization

\section{Introduction and Literature Review}

\section{Noise Pollution}

Noise pollution is a disturbance to the human environment that is escalating at such a high rate that it will become a major threat to the quality of human lives. Noises in all areas, especially in urban areas, have been increasing rapidly. Poor urban planning gives rise to noise pollution. In simple terms, noise is unwanted sound. Sound is a form of energy which is emitted by a vibrating body and on reaching the ear causes the sensation of hearing through nerves. Sounds produced by all vibrating bodies are not audible. The frequency limits of audibility are from $20 \mathrm{HZ}$ to $20,000 \mathrm{HZ}$.
Sound pressure level (SPL) or sound level $L_{p}$ is a logarithmic measure of the effective sound pressure of a sound relative to a reference value. It is measured in decibels $(\mathrm{dB})$ above a standard reference level. The commonly used reference sound pressure in air is $\mathrm{P}_{\text {ref }}=$ $20 \mu \mathrm{Pa}$ (rms), which is usually considered the threshold of human hearing.

\section{Sound Intensity}

$>\quad$ For a specified direction and point in space, the average rate at which sound energy is transmitted through a unit area perpendicular to the specified direction.

The measure of a ratio of two sound intensities is

$$
L_{1}=10 \log _{10}\left(\frac{I_{1}}{I_{0}}\right) d B
$$


If $\mathrm{I}_{0}$ is the standard reference sound intensity

$$
I_{0}=10^{-12} W / m^{2}
$$

(W = watt), then instead of "dB SPL" we use "dB SIL". $(\mathrm{SIL}=$ sound intensity level).

\section{Permissible Noise Level Criteria}

The permissible noise pollution criterion is shown in Table 1. Day time shall mean from 6.00 a.m. to 10.00 p.m. Night time shall mean from 10.00 p.m. to 6.00 a.m. Silence zone is defined as an area comprising not less than 100 meters around hospitals, educational institutions and courts. The silence zones are zones which are declared as such by the competent authority. Mixed categories of areas may be declared as one of the four above mentioned categories by the competent authority.

\begin{tabular}{|c|c|c|c|}
\hline 5.No & $\begin{array}{c}\text { Category of area } \\
\text { (Code) }\end{array}$ & $\begin{array}{c}\text { Day time } \\
\text { Intensity(dB) }\end{array}$ & $\begin{array}{c}\text { Night time } \\
\text { ntensity(dB) }\end{array}$ \\
\hline 1 & Industrial Area (A) & 75 & 70 \\
\hline 2 & Commercial Area (B) & 65 & 55 \\
\hline 3 & Residential Area (C) & 55 & 45 \\
\hline 4 & Silence Zone (D) & 50 & 40 \\
\hline
\end{tabular}

Table 1: Permissible Noise Criteria in India.

\section{Traffic Noise and its Health Effects}

Traffic noise has become one of the main environmental quality problems in developed countries and causing noise annoyance among the citizens. In Europe about 113 million citizens $(17 \%$ of the population) are exposed to ambient noise levels above Leq $65 \mathrm{~dB}(\mathrm{~A})$ and about 9.7 million citizens are exposed to noise levels above $75 \mathrm{~dB}(\mathrm{~A})$ [1]. The main source of acoustic nuisances is road traffic. There is a growing amount of evidence that road traffic noise increases about 1-3 decibels a year in most cities. According to prognosis, the noise load will double in a 15-year period $[2,3]$. Excess noise has a wide range of effects on individuals, ranging from disturbance to chronic stress and damage to hearing. Therefore, the World Health Organization (WHO) has attributed noise to occupational risk factors [4]. Traffic noise causes annoyance, emotional distress, and chronic stress and increases the risk of hypertension [5-7]. Long-term noise causes changes in homeostasis, which are accompanied by disorders in heart rhythm, muscle tenseness and changes in brain electrical potentials [8]. A positive association was found between noise annoyance and serum lipid levels [9], exposure to noise and fibrinogen, and plasma viscosity [10], causal risk factors of ischemic heart disease (IHD). Exposure to noise increases physiological stress indicators - catecholamine's and steroid hormones and through the neurohumoral pathway stimulates changes in the cardiovascular system, stimulates arterial hypertension, development of IHD [11,12], and might increase myocardial infarction (MI) risk $[13,14]$. There are only a few published community studies, among them Berlin case-control study $[15,16]$ and Cearphilly and Speedwell cohort studies [17]. Epidemiological studies have shown that noise-induced health effects depend on noise character and exposure time, as well as duration and other environmental factors. Individual sensitivity, age and susceptibility to noise determined noiseinduced responses. Large individual differences in sensitivity to noise co-vary with expressed annoyance resulting from noise. Lack of measurements of noise levels in human settlements, difficulty in exposure quantification and the small number of cases are factors of great importance why epidemiologic evidence of cardiovascular effects caused by environmental noise exposure is still limited.

Additional studies since then have also found an association between work-related noise and blood pressure [2-5]. Although one of the studies has suggested the effect is only transient in people under the age of fifty. Possible biological mechanisms for the association between noise and high blood pressure are: 1) release of stress hormones such as steroids; and 2) activation of the sympathetic nervous system with release of epinephrine. Animal models have shown both these changes. Additionally, a recent article demonstrated genetic changes (damage) in rat heart cells. These changes persisted after noise exposure ceased [6]. Finally chronic noise exposure has been associated with hyperlipidaemia [7]. Hyperlipidaemia may by causing atherosclerosis increase the risk for hypertension.

\section{Methodology}

The study included four sites of city namely; interstate bus terminal Jalandhar, Jyoti Chowk, Maqsudan Chowk, Rama mandi. A weighted (Leq) ambient noise was assessed by using a Quest sound level meter "ANSI SI. 43-1997(R 2002) Type-1, model SOUNDPRO SE/DL". OSHA norms for hearing conservation were incorporated including an exchange rate of $5 \mathrm{~dB}(\mathrm{~A})$, criterion level at $90 \mathrm{~dB}(\mathrm{~A})$, criterion time of $8 \mathrm{hrs}$, threshold level $=80 \mathrm{~dB}(\mathrm{~A})$, upper limit $=$ $140 \mathrm{~dB}(\mathrm{~A})$ and with $\mathrm{F} / \mathrm{S}$ response rate. In. The sound pressure was recorded for 15 minutes each time on each work station and one long term recording for $8 \mathrm{hrs}$ was done. At each section sound pressure was recorded at least 4-5 times at different locations where the movement of the workers was most frequent. There was hardly a difference of 0.5 to $1.0 \mathrm{~dB}$ (A) between long term recoding and short term recording. Most 


\section{Ergonomics International Journal}

\section{Results}

The results of the study revealed that noise levels at various locations at Shaheed-E-Azams Bhagat Singh interstate bus terminal Jalandhar city were found be significantly higher than the prescribed limits of 65
$\mathrm{dB}(\mathrm{A})$ as shown in Table 2-Table6. At the same time Punjab Armed Police (PAP) Chowk was found to be the second highest area of traffic noise pollution. Subsequently Jyoti Chowk and Maqsudan Chowk were found to be the area moderate traffic noise pollution.

\begin{tabular}{|c|c|c|c|c|}
\hline S.No. & Time & Maximum(DB) & Minimum(DB) & Average(DB) \\
\hline 1 & $8: 00 \mathrm{AM}-10: 00 \mathrm{AM}$ & 71 & 68.3 & 70.39 \\
\hline 2 & $12: 00 \mathrm{PM}-2: 00 \mathrm{PM}$ & 76.1 & 73.4 & 74.98 \\
\hline 3 & $4: 00 \mathrm{PM}-6: 00 \mathrm{PM}$ & 78 & 73 & 74.82 \\
\hline 4 & $8: 00 \mathrm{AM}-10: 00 \mathrm{AM}$ & 73.5 & 68.4 & 70.98 \\
\hline 5 & $12: 00 \mathrm{PM}-2: 00 \mathrm{PM}$ & 76.9 & 75.4 & 75.94 \\
\hline 6 & $4: 00 \mathrm{PM}-6: 00 \mathrm{PM}$ & 76.5 & 73.1 & 70.41 \\
\hline 7 & $8: 00 \mathrm{AM}-10: 00 \mathrm{AM}$ & 72.7 & 68.2 & 75.86 \\
\hline 8 & $12: 00 \mathrm{PM}-2: 00 \mathrm{PM}$ & 76.1 & 75.3 & 75.28 \\
\hline 9 & $4: 00 \mathrm{PM}-6: 00 \mathrm{PM}$ & 75.8 & 73.6 & \\
\hline
\end{tabular}

Table 2: Noise level during peak hours at Shaheed-E-Azams Bhagat Singh interstate bus terminal Jalandhar.

\begin{tabular}{|c|c|c|c|c|}
\hline S.No. & Time & Maximum(dB) & Minimum(dB) & Average(dB) \\
\hline 1 & $8: 00 \mathrm{AM}-10: 00 \mathrm{AM}$ & 56.5 & 47.2 & 52.73 \\
\hline 2 & $12: 00 \mathrm{PM}-2: 00 \mathrm{PM}$ & 68.5 & 66.0 & 67.65 \\
\hline 3 & $4: 00 \mathrm{PM}-6: 00 \mathrm{PM}$ & 69.9 & 62.0 & 65.75 \\
\hline 4 & $8: 00 \mathrm{AM}-10: 00 \mathrm{AM}$ & 54.6 & 46.5 & 52.34 \\
\hline 5 & $12: 00 \mathrm{PM}-2: 00 \mathrm{PM}$ & 71.2 & 66.2 & 67.91 \\
\hline 6 & $4: 00 \mathrm{PM}-6: 00 \mathrm{PM}$ & 68 & 61.9 & 64.68 \\
\hline 7 & $8: 00 \mathrm{AM}-10: 00 \mathrm{AM}$ & 55.6 & 47.3 & 52.30 \\
\hline 8 & $12: 00 \mathrm{PM}-2: 00 \mathrm{PM}$ & 72.9 & 64.3 & 68.28 \\
\hline 9 & $4: 00 \mathrm{PM}-6: 00 \mathrm{PM}$ & 73.5 & 61.4 & 65.15 \\
\hline
\end{tabular}

Table 3: Noise level during peak hours at Jyoti Chowk.

\begin{tabular}{|c|c|c|c|c|}
\hline S.No. & Time & Maximum(dB) & Minimum(dB) & Average(dB) \\
\hline 1 & $8: 00 \mathrm{AM}-10: 00 \mathrm{AM}$ & 54.6 & 47.1 & 53.52 \\
\hline 2 & $12: 00 \mathrm{PM}-2: 00 \mathrm{PM}$ & 63.2 & 59.2 & 61.76 \\
\hline 3 & $4: 00 \mathrm{PM}-6: 00 \mathrm{PM}$ & 62.3 & 56.9 & 59.1 \\
\hline 4 & $8: 00 \mathrm{AM}-10: 00 \mathrm{AM}$ & 55.0 & 51.7 & 53.85 \\
\hline 5 & $12: 00 \mathrm{PM}-2: 00 \mathrm{PM}$ & 65.2 & 58.9 & 61.33 \\
\hline 6 & $4: 00 \mathrm{PM}-6: 00 \mathrm{PM}$ & 62.4 & 58.3 & 59.51 \\
\hline 7 & $8: 00 \mathrm{AM}-10: 00 \mathrm{AM}$ & 52.8 & 46.2 & 49.58 \\
\hline 8 & $12: 00 \mathrm{PM}-2: 00 \mathrm{PM}$ & 65.1 & 52.9 & 60.36 \\
\hline 9 & $4: 00 \mathrm{PM}-6: 00 \mathrm{PM}$ & 65.8 & 58.6 & 61.376 \\
\hline
\end{tabular}

Table 4: Noise level during peak hours at Maqsudan Chowk.

\begin{tabular}{|c|c|c|c|c|}
\hline S.No. & Time & Maximum(dB) & Minimum(dB) & Average (dB) \\
\hline 1 & $8: 00 \mathrm{AM}-10: 00 \mathrm{AM}$ & 59.95 & 53.15 & 56.5875 \\
\hline 2 & $12: 00 \mathrm{PM}-2: 00 \mathrm{PM}$ & 71.525 & 65.3 & 68.91875 \\
\hline 3 & $4: 00 \mathrm{PM}-6: 00 \mathrm{PM}$ & 70.075 & 64.725 & 67.68125 \\
\hline 4 & $8: 00 \mathrm{AM}-10: 00 \mathrm{AM}$ & 58.5 & 53.45 & 56.29375 \\
\hline 5 & $12: 00 \mathrm{PM}-2: 00 \mathrm{PM}$ & 71.475 & 65.95 & 68.84375 \\
\hline 6 & $4: 00 \mathrm{PM}-6: 00 \mathrm{PM}$ & 69.15 & 64.325 & 54.475 \\
\hline 7 & $8: 00 \mathrm{AM}-10: 00 \mathrm{AM}$ & 56.925 & 52.425 & 66.46875 \\
\hline 8 & $12: 00 \mathrm{PM}-2: 00 \mathrm{PM}$ & 68.95 & 64.05 & 66.63125 \\
\hline 9 & $4: 00 \mathrm{PM}-6: 00 \mathrm{PM}$ & 68.625 & 64.55 & \\
\hline
\end{tabular}


Table 5: Noise level during peak hours at PAP Chowk.

\begin{tabular}{|c|c|c|c|c|c|}
\hline Station name & $\begin{array}{c}\text { Maximum } \\
\text { noise level }\end{array}$ & Noise range & $\begin{array}{c}\text { Comparison with } \\
\text { Indian standard }\end{array}$ & Region & Remarks \\
\hline ISBT Jalandhar & $78 \mathrm{~dB}$ & $68.3-78 \mathrm{~dB}$ & $>65 \mathrm{~dB}$ & Commercial Area & Highly polluted \\
\hline Jyoti Chowk & $73.5 \mathrm{~dB}$ & $47.2-73.5 \mathrm{~dB}$ & $>65 \mathrm{~dB}$ & Commercial Area & Moderately Polluted \\
\hline PAP Chowk & $71.5 \mathrm{~dB}$ & $52.5-71.5 \mathrm{~dB}$ & $>65 \mathrm{~dB}$ & Commercial Area & Moderately Polluted \\
\hline Maqsudan Chowk & $65.8 \mathrm{~dB}$ & $47.1-65.8 \mathrm{~dB}$ & $>65 \mathrm{~dB}$ & Commercial Area & Moderately polluted \\
\hline
\end{tabular}

Table6: Comparative Analysis Jalandhar city, Punjab.

\section{References}

1. Van Kempen EEMM, Kruize H, Boshuizen HC, Ameling CB, Staatsen BAM, et al. (2002) The Association Between Noise Exposure and Blood Pressure and Ischemic Heart disease: A MetaAnalysis. Environmental Health Perspectives 110(3): 307-317.

2. Melamed S, Fried Y, Froom P (2001) The Interactive Effect of Chronic Exposure to Noise and Job Complexity on Changes in Blood Pressure and Job Satisfaction: A Longitudinal Study of Industrial Employees. Journal Occupational Health Psychology 6(3): 182-195.

3. Fogari R, Zoppi A, Corradi L, Marasi G, Vanasia A, et al. (2001) Transient But Not Sustained Blood Pressure Increments by Occupational Noise. An Ambulatory Blood Pressure Measurement Study. Journal Hypertension 19(6): 1021-1027.

4. Tomei F, Fantini S, Tomao E, Baccolo TP, Rosati MV (2000) Hypertension and Chronic Exposure to Noise. Archives of Environmental Health 55(5): 319-325.

5. Chang TY, Jain RM, Wang CS, Chan CC (2003) Effects of Occupational Noise Exposure on Blood Pressure. Journal Occupational and Environmental Medicine 45(12): 1289-1296.

6. Lenzi P, Frenzilli G, Gesi M, Ferruci M, Lazzeri G, et al. (2003) DNA Damage Associated with Ultrastructural Alterations in Rat Myocardium After Loud Noise Exposure. Environmental Health Perspectives 111(4): 467-471.

7. Campbell KC, Rybak LP, Khardori R (1996) Sensorineural Hearing Loss and Dyslipidemia. American Journal of Audiology 5: 11-14.
8. Ali S, Tamura A (2001) Diagnostic study for traffic noise problems in Greater Cairo, Egypt. In: Proceeding of inter-noise 2001, TRID, The Hague, The Netherlands, pp: 1177-1181.

9. Reports of Minster of Egyptian Transportation about road traffic in Greater Cairo. Al-Ahram Newspaper.

10. Ali S, Tamura A (2001) Road traffic \& traffic noise problems in Greater Cairo, Egypt: characteristics, countermeasure taken and future plans. In: Proceeding of 17 th International Congress on Acoustics, Rome, Italy.

11. Ali S, Tamura A (2002) Road traffic noise mitigation strategies in Greater Cairo, Egypt. Applied Acoustics 63(11): 1257-1265.

12. Onuu MU (2000) Road traffic noise in Nigeria: measurements, analysis and evaluation of nuisance. Journal of Sound and Vibration 233(3): 391-405.

13. Sayed AG (2002) Number of vehicles in Greater Cairo's roads with using GPS. Newspaper of Vehicles (Egyptian Newspaper).

14. Schultz TJ (1982) Community noise rating. Applied Science, England.

15. Miguel A, Garcia A (1998) A Social survey on the effect of environment noise on the residents of Pamplona, Spain. Applied Acoustics 53(4): 245-253.

16. (1994) Egyptian environmental law no. 4 of year 1994. Cairo, Egyptian Ministry of Environment.

17. Ali SA, Tamura A (2003) Applied Acoustics 64: 815823. 